\title{
99
}

\section{Computing History of the Nordic Countries}

Chair: Peter Bollerslev (DK)

Panel: Leo Højsholt-Poulsen (DK), John Impagliazzo (US), Jan Wibe (NO), Erling Schmidt (DK)

Keywords: computing history, languages, programming, informatics as a study topic

Peter Bollerslev, President of IFIP, stated that computing history is a rich area of academic and practical interest.

John Impagliazzo, Chair of IFIP WG9.7 (History of Computing), related how in Sweden Georg Scheutz built the first prototype of the Difference Engine in 1822 and the actual machine from 1840 to 1853 . Willgodt Odhner designed the first commercial calculator in 1875, used for almost 100 years. Another, built by Carl Fridén in 1922, remained commercial until the 1970s. The Swedish government authorised the construction of first commercial computer, Binär Automatisk ReläKalulator (BARK), used from 1950 to 1955; from 1953 then developed the Binär Electronisk Sekvens-Kalulator (BESK) all-electronic computer that in 1954 was the fastest in the world. 12 BESK-type machines were made; one is quasi-operational at the University of Lund. In 1957 Facit designed EDB, the first Swedish commercial computer, while Saab designed the Saab Räkneautomat (SARA) for in-house calculations for aircraft. Datasaab (Saab) produced in 1962 the D21 computer, a commercial version. Ericsson, a force in communications since 1876 , is today dominant in wireless communications and technology.

Erling Schmidt, of the School Authorities of Aalborg, highlighted achievements in Denmark, from the educational perspective. The development of Denmark's first computer - the Dansk Automatic Sekvens Kalkulator (DASK) - was an extension of the Swedish BESK after cooperation between Danish and Swedish scientists. Denmark's first educational computer was a binary-digital converter, introduced in Danish 
schools in 1968. By the early 1970s, it was clear that computers should be an integral part of education. In 1972, the Ministry of Education issued the socalled Johnsen-report, a plan for computers in the educational system at all levels. Although not implemented immediately, it generated much interest and spurred using computers in the school curriculum. The follow-up work by Bollerslev and others in 1982 and 1983, entitled Datalcere, led to an infusion of computers in the Danish teacher education and school system.

Jan Wibe of Trondheim Universitet, the Norwegian University of Science and Technology, stated that Norway's early interest in computers was educational. The philosophy was to treat informatics as a subject area in its own right, to integrate computers in other subjects of learning, and to include computers as part of teacher education and training. From 1970 to 1983, all Norwegian schools offered an optional course in BASIC programming In 1983, the Minister of Education created a taskforce, Datasekretariatet, which fostered software development and projects in schools. All teachers had to have at least 40 hours of computer education in their training. By 1990, computers were integrated in all schools and a required component of all teacher education, which a further emphasis on training from 1990 to 1996. Between 1996 and 1999, a national four-year plan emphasised research, the development of learning resources, the use of computer projects in schools, and the deployment of distance education. Norway's new four-year plan (2000-2003) may be found at $<\mathrm{http}: / / \mathrm{www}$. dep.no/kuf/html/ikt/>.

Leo Højsholt-Poulsen of UNI-C in Århus, recalled his early days of computing - number crunching of mathematical equations. In the 1970s and the 1980s, in education the concentration was on programming and programming languages. ICT in schools was synonymous with programming, in BASIC. By 1980 the home-grown language of Comal became the language of choice in the school systems. Later, Pascal was used. In 1987, the Nordic countries developed Dataprogramgruppen, a consortium under the auspices of the Nordic Council of Ministers for the purpose of exchanging educational software between the Nordic countries. Between 1987 and 2000, this 'Baastad Model' encompassed over 250 educational programs that were part of the consortium pool. The model has helped the Nordic countries to stay abreast with ICT in schools and provided an avenue of leadership to explore new educational ideas in a technical society.

The audience, interested in this Nordic history, suggested that IFIP be more proactive in this area, possibility through a conference so it could be explored in greater depth. 